\title{
Economic Analysis of Growing Grafted Cucumber Plants for High Tunnel Production
}

\author{
Orlando F. Rodriguez Izaba ${ }^{1}$, Wenjing Guan ${ }^{1}$, \\ and Ariana P. Torres ${ }^{1,2}$
}

ADDITIONAL INDEX WORDs. early production, partial budget analysis, rootstock, scion, sensitivity analysis

Summary. Cucumber (Cucumis sativus) is one of the most important vegetables produced and consumed in the United States. In the midwestern United States, a major obstacle to spring cucumber production is low soil temperatures during plant establishment. High tunnel is a popular tool for season extension of vegetable production. Low soil temperature is a challenge for cucumber production even inside high tunnels. Grafting is a cultural practice known to help control soilborne diseases and improve plants' tolerance to abiotic stresses. Recent studies found that using grafted cucumber plants with cold-tolerant rootstocks greatly benefited earlyseason seedless cucumber production in high tunnels. The objective of this study was to analyze the economic feasibility of growing grafted cucumber in high tunnels. A comparison of partial costs and returns between growing grafted and nongrafted cucumbers in a high tunnel in Vincennes, IN, was conducted. Data were used to develop a partial budget analysis and sensitivity tests. Data included production costs, marketable yield, and price of cucumber through different market channels. This study provided a baseline reference for growers interested in grafting seedless cucumber and for high tunnel production. Although costs of grafted transplants were higher, their yield and potential revenue helped to offset the higher costs. Results indicated that grafting can help farmers increase net returns through the increasing yield of grafted plants. Results from the sensitivity analysis illustrated how the increased yield of grafted cucumbers offsets the extra cost incurred in the technique while providing a higher revenue. While actual production costs for individual farmers may vary, our findings suggested that grafting can be an economically feasible tool for high tunnel seedless cucumber production.

C ucumber (Cucumis sativus) is a widely produced and consumed crop in the United States. On the supply side, the country produced 19,944,700 cwt in 2019 under 100,800 acres [U.S. Department of Agriculture (USDA), 2020a]. On the

Received for publication 1 Oct. 2020. Accepted for publication 20 Jan. 2021.

Published online 16 February 2021.

${ }^{1}$ Department of Horticulture and Landscape Architecture, Purdue University, 625 Agriculture Mall Drive, West Lafayette, IN 47907

${ }^{2}$ Department of Agricultural Economics, Purdue University, 403 W. State Street, West Lafayette, IN 47907

This material is supported by the National Institute of Food and Agriculture, U.S. Department of Agriculture (USDA), under award number 2017-38640-26916 through the North Central Region SARE program under project number LNC17-390.

The USDA is an equal opportunity employer and service provider. Any opinions, findings, conclusions, or recommendations expressed in this publication are those of the author(s) and do not necessarily reflect the view of the USDA.

W.G. is the corresponding author. E-mail: guan40@ purdue.edu.

This is an open access article distributed under the CC BY-NC-ND license (https://creativecommons.org/ licenses/by-nc-nd/4.0/).

https://doi.org/10.21273/HORTTECH04747-20 consumer side, consumption of cucumber per capita was $8 \mathrm{lb}$ in 2019 , a $25 \%$ increase since 2000 (USDA, 2020b). Although domestic production has tried to keep up with this growing demand, $73 \%$ of cucumber demand is met by imports (USDA, 2020b).

Certain segments of American consumers prefer locally produced fresh vegetables (Torres et al., 2017), yet the supply of local cucumbers mainly occurs in the summer. A major obstacle deterring early cucumber production is low temperatures in the midwestern United States. Soil temperatures lower than $63^{\circ} \mathrm{F}$ greatly suppress water and nutrients absorption (Welbaum, 2015), while soil temperatures below $55^{\circ} \mathrm{F}$ may cause cucumber establishment failure (Guan et al., 2018).

Protected agriculture, particularly high tunnels, are increasingly becoming an important tool for season extension production of many vegetable crops, including cucumbers (Knewtson et al., 2010; Lamont, 2009). Yet high tunnels are typically not equipped with advanced environmental control systems (Carey et al., 2009). As a result, crops suffer from low soil temperatures in the spring even inside high tunnels (Hunter et al., 2012).

Vegetable grafting is a cultural practice known to help control soilborne diseases and improve plants' tolerance to abiotic stresses; it has been proposed as an alternative to overcome the challenge associated with low temperatures (Lee et al., 2010; Louws et al., 2010; Schwarz et al., 2010). Grafted plants combine the beneficial characteristics of both the rootstock and scion plants (Lee et al., 2010). Although vegetable grafting is a wellestablished practice in Asian countries, it was only recently introduced in the United States (Kubota et al., 2008; Louws et al., 2010).

The increased adoption of high tunnels in the United States has encouraged the use of grafting technology (Louws et al., 2010). Meyer (2016) reported that for tomato (Solanum lycopersicum) production under protected structures, using grafted plants has the potential to increase tomato yields regardless of the presence of soilborne diseases. Rysin et al. (2015) found that the higher economic returns of growing tomato under protected structures can compensate for the cost of using grafted plants.

Kubota et al. (2008) noted that grafted tomato seedlings can cost up to $\$ 0.90 /$ plant, while the price of nongrafted seedlings was $\approx \$ 0.40 /$ plant. Barrett et al. (2012) reported grafting tomatoes added $\$ 0.6 \mathrm{l} / \mathrm{plant}$ compared with nongrafted plants in an organic transplant production

\begin{tabular}{llll}
\hline $\begin{array}{l}\text { Units } \\
\begin{array}{l}\text { To convert U.S. to SI, } \\
\text { multiply by }\end{array}\end{array}$ & U.S. unit & SI unit & $\begin{array}{l}\text { To convert SI to U.S., } \\
\text { multiply by }\end{array}$ \\
\hline 0.4047 & $\mathrm{acre}(\mathrm{s})$ & $\mathrm{ha}$ & 2.4711 \\
0.0454 & $\mathrm{cwt}$ & $\mathrm{Mg}$ & 22.0462 \\
0.3048 & $\mathrm{ft}$ & $\mathrm{m}$ & 3.2808 \\
0.4536 & $\mathrm{lb}$ & $\mathrm{kg}$ & 2.2046 \\
1.1209 & $\mathrm{lb} / \mathrm{acre}$ & $\mathrm{kg} \cdot \mathrm{ha}^{-1}$ & 0.8922 \\
33.9057 & $\mathrm{oz} / \mathrm{yard}^{2}$ & $\mathrm{~g} \cdot \mathrm{m}^{-2}$ & 0.0295 \\
$\left({ }^{\circ} \mathrm{F}-32\right) \div 1.8$ & ${ }^{\circ} \mathrm{F}$ & ${ }^{\circ} \mathrm{C}$ & $\left({ }^{\circ} \mathrm{C} \times 1.8\right)+32$
\end{tabular}


system in Florida. They also found that under severe root-knot nematode (Meloidogyne incognita) pressure, growing grafted tomato can be an economically feasible strategy to control pests. Rivard et al. (2010) reported additional grafting cost per tomato plant was between $\$ 0.46$ and $\$ 0.74$ for commercial farming operations in North Carolina and Pennsylvania. Using grafted watermelon (Citrullus lanatus) plants was found to be economically feasible, especially when fusarium wilt (Fusarium oxysporum) is present, which may cause yield loss up to $100 \%$ (Taylor et al., 2008). Even though these previous studies are not related to high tunnels, they give us an insight about the economic analyses of vegetable grafting.

Researchers expect that grafting will expand in the United States as more benefits are discovered, highquality grafted transplants become more available, and prices for the grafted plants are more affordable (Kubota et al., 2008; Lee et al., 2010). The continued increase in demand for organic and local foods may also help fuel the interest in vegetable grafting in the United States (Greene et al., 2009), as making locally grown vegetables available year-round can help farmers and consumers build stronger relationships and obtain price premiums (Torres et al., 2017).

Recent studies found using grafted plants with cold-tolerant rootstocks greatly benefited early season seedless cucumber production in high tunnels (Guan et al., 2018). Grafted cucumber plants can increase transplants survival and enhance plant growth when soil temperatures were less than optimal. With carefully selected rootstocks, yields of cucumbers can be greatly improved by using grafted plants in high tunnels (Guan et al., 2020). Despite the promising results, to our knowledge, no studies have examined the economic feasibility of using grafted cucumber plants for high tunnel production. Limited diffusion of grafted cucumber and a lackof economic feasibility studies of cucumber grafting in the United States represent a lost opportunity to increase early-season availability of locally grown cucumbers.

The objective of this study was to analyze the economic feasibility of growing grafted cucumber in high tunnels. A comparison of partial costs and returns between grafted and nongrafted cucumber was conducted. Data were used to develop a partial budget analysis and a sensitivity analysis. Data included production costs, marketable yield, and cucumber price through different market channels. Our goal is to increase farmers' knowledge of the economic benefits of growing grafted cucumbers in high tunnels. Our findings can help growers and extension personnel to better evaluate the economic feasibility of growing grafted cucumbers for high tunnel production.

\section{Materials and methods}

Transplant production. The study was conducted at the Southwest Purdue Agricultural Center (SWPAC), Vincennes, IN, from 2017 to 2019 . The experiments included nongrafted cucumber and cucumber grafted on rootstock 'Cobalt' hybrid squash [Cucurbita maxima $\times$ C. moschata (Rijk Zwaan, Fijnaart, The Netherlands)]. Rootstock seeds were donated by the seed company. Cucumber cultivar Socrates (Johnny's Selected Seeds, Winslow, ME) was used as the scion and nongrafted controls.

Nongrafted plants and rootstock seeds were planted in 50-cell trays. Scion seeds for the grafted plants were sown in 128-cell trays 1 to $2 \mathrm{~d}$ later than the rootstock seeds. Seeds were planted in a greenhouse around 20 Feb. for all 3 years. Grafting was performed 1 week later after scion seeds were planted, at the time when both rootstock and scion plants had the first true leaf emerged. Grafting was performed indoor using the splice graft method (Guan, 2019). The graft healing was conducted in a plant growth chamber (AR-95L3 Arabidopsis; Percival Scientific, Perry, IA) with temperatures set at $30 / 28{ }^{\circ} \mathrm{C}$ $\mathrm{day} /$ night and $14 \mathrm{~h}$ light at 200 to $400 \mu \mathrm{mol} \cdot \mathrm{m}^{-2} \cdot \mathrm{s}^{-1}$ light intensity. Relative humidity $(\mathrm{RH})$ of the growth chamber was set at $60 \%$. The grafted plants were sprayed with water immediately after grafting and covered with a plastic film. Edges of the plastic film were sealed to create a micro condition with $100 \% \mathrm{RH}$ around grafted plants. The film was removed for $\approx 2$ min on days 2 and 3 post-grafting, and one slit was cut for each tray on day 4. More slits were cut on days 5 and 6 . The film was completely taken off on day 7 . Nongrafted plants were also grown inside the growth chamber for the same period but without covering. Both grafted and nongrafted plants were moved back to greenhouse $7 \mathrm{~d}$ after grafting.

High TUNNEL CUCUMBER PRODUCTION. In southern Indiana, the average date with air temperature at $36^{\circ} \mathrm{F}$ or lower ranged from $17 \mathrm{Apr}$. to 24 Apr. (Purdue University, 2020). Growers whose target is to sell at early-season market typically plant warm-season crops inside high tunnels around end of March to early April in the region. In this study, cucumber plants were grown in 30ft-wide and 96-ft-long high tunnels located at SWPAC. Grafted and nongrafted cucumbers were planted in black plastic mulch covered beds around 20 Mar. for all 3 years. Row cover (1.5 oz/yard ${ }^{2}$, GR-RCl5; GreenhouseMegastore, Los Angeles, CA) was used for frost protection when the lowest air temperatures outside high tunnel were below $36^{\circ} \mathrm{F}$. Plants encountered the lowest average soil temperatures after transplanting in 2018, with the recorded minimal soil temperature at $46{ }^{\circ} \mathrm{F}$ (Guan et al., 2020). The in-row plant spacing was $1 \mathrm{ft}$. The experimental design was a randomized complete block design. Five plants were included in each block. Four blocks were used in 2018, and three blocks were used in 2017 and 2019. All plants survived in 2017 , but $91.2 \%$ and $77.7 \%$ of nongrafted plants died in 2018 and 2019 after transplanting due to low soil temperature stress (Guan et al., 2020). Nongrafted plants were replanted on 10 Apr. 2018 and 27 Mar. 2019.

All plants were fertigated three times per day at a rate of $1 \mathrm{lb} /$ acre nitrogen $(\mathrm{N})$ per day as described in Guan et al. (2020). A total of 100 to $130 \mathrm{lb} /$ acre $\mathrm{N}$ was applied per year depending on the length of the harvest season. Disease and insect pests were controlled according to Midwest Vegetable Production Guide for Commercial Growers (Egel et al., 2019). Plants were trellised to a single leader system. Suckers as well as lower leaves of each vine were pruned. Plants were harvested from April to the end of July in 2018, and to the end of June in 2017 and 2019. Harvest was conducted three times per week. 
Cucumbers that were misshaped or scarred were separated from the marketable fruit. Marketable and unmarketable fruit weight and fruit number were recorded.

ECONOMIC ANALYSES. A partial budget analysis was used to assess the cost-effectiveness comparison between grafted and nongrafted cucumbers. This analysis is used as an economic tool to determine how a different production system can affect the returns of the farming operation (Sydorovych et al., 2008). Other studies have used similar methodology to assess partial revenue of grafted vegetables (Barrett et al., 2012; Rivard et al., 2010; Taylor et al., 2008). The partial budget analysis focuses only on the changes in revenues and costs that result from implementing the grafting technique, while omitting production and packing costs (e.g., land preparation, irrigation, fertilizer, pest control) that remained equal between grafted and nongrafted experiments. We addressed the effect of the change in costs of grafted production inputs on the change of the partial revenue of the cucumber operation. A partial budget analysis can assist decision-makers in evaluating the difference between grafted and nongrafted production systems to decide whether to adopt the technology (Alimi and Manyong, 2000).

The partial budget was computed using data from materials and labor used at the time of the study. This type of analysis does not consider fixed costs that remain constant for both grafted and nongrafted plants, such as land value, costs of greenhouses, and healing chamber. The cost of healing chamber was not included in the partial cost analysis because both grafted and nongrafted plants were placed in the growth chamber for $7 \mathrm{~d}$ post-grafting to ensure a similar growing condition for grafted and nongrafted plants. Grafted plants were covered with a clear plastic while nongrafted plants were not; therefore, the cost for plastic cover was accounted into miscellaneous grafting supplies.

Sources and prices for materials used to produce grafted and nongrafted cucumber plants are presented in Table 1. Inputs for the total grafting cost were based on producing 1000 grafted and nongrafted transplants. A grafting survival rate of $80 \%$ as achieved in this study was used to calculate seed and material costs for producing grafted plants. Both rootstock and scion seeds were overseeded by $5 \%$ to account for $95 \%$ germination rate. The hourly wage used for all labor calculations (seed sowing and care, grafting labor, and post-graft care) was $\$ 11.94 / \mathrm{h}$, which is the 2018 mean hourly wage for farm, nursery, and greenhouse workers in the state of Indiana (U.S. Department of Labor, 2019). Grafting speed was estimated at the time of the study with an average of 100 plants per person per hour. Similar grafting rates were used in other studies (Barrett et al., 2012; Rivard et al., 2010).

Cucumbers from this experiment were not sold through any market at the time of the study. We used 2018 prices of two market channels commonly used by cucumber growers (i.e., farmers' market and retail stores) to provide a gross revenue comparison between markets. Price variation across markets can help us understand how a change in markets may impact the partial revenue of grafted vs. nongrafted cucumbers. Annual median farmers' market price $(\$ 1.70 / \mathrm{lb})$ came from a price database published by Purdue Horticulture Business Extension Program (Purdue University, 2018). Annual median retail price $(\$ 1.10 / \mathrm{lb})$ came from USDA pricing reports (USDA, 2018).

Gross revenue per plant was computed by multiplying the marketable yield per plant times the cucumber price for each market channel (i.e., farmers market and retail). Partial profit per plant was computed as the gross revenue per plant minus partial transplant cost and partial harvesting/pruning cost without considering other production costs (e.g., irrigation, fertilizer, pesticide, harvest). Grafted plants had higher yield primarily in the first month of harvest until $\approx 15$ May (Guan et al., 2020). They require extra harvesting and plant pruning labor in the first month of harvest. The labor required for harvesting and pruning was recorded based on one row of 80 plants. Grafted plants require $\approx 1.5 \mathrm{~h}$ labor per week per row compared with $0.5 \mathrm{~h}$ labor per week per row for nongrafted plants in the first month. The hourly wage $\$ 11.94 / \mathrm{h}$ was used to calculate the partial cost for harvesting and pruning, which resulted in $\$ 0.89 /$ plant of grafted plant and $\$ 0.30 /$ plant of nongrafted plant.

Sensitivity analysis illustrates how changes in two independent variables can affect one dependent variable. For example, Djidonou et al. (2013) developed sensitivity analysis to evaluate how market prices and grafted transplant cost affect the returns of grafted tomato. Similar to Barrett et al. (2012) and Taylor et al. (2008), we computed sensitivity analysis to calculate the effect of changes in market price and yield on the partial profit of the farming activity. The range of cucumber prices per pound used for the sensitivity analysis was derived from the range of prices found in farmers' markets and retail stores. Average yield was analyzed for each year (SAS version 9.4; SAS Institute, Cary, NC), and yield was allowed to vary up to 3 standard deviations to capture yield variation in the experiments.

\section{Results}

Transplant cost analyses. Table 2 illustrated the comparison of partial costs between grafted and nongrafted cucumber transplants. Items in the partial cost analysis included seeds (scion for both grafted and nongrafted, and rootstock for grafted plants), seedling production (potting soil, trays, and seed sowing and care), grafted transplant production (labor, clips, and supplies only applicable to grafted plants), and post-graft healing. Grafted cucumber plants had a partial cost of $\$ 1.33$ each, while the cost of nongrafted plants was $\$ 0.48$ each. In other words, grafting increased the production cost of cucumber by $\$ 0.85 /$ plant.

The higher cost of grafted plants can be mainly attributed to scion and rootstock seed costs, which accounted for $46 \%$ of the partial cost. Grafting materials and labor represented $27 \%$ and $21 \%$ of the partial cost, respectively. The other $6 \%$ of partial cost was due to seedling production inputs (potting soil and trays).

Yield, PARTIAL PROFITS, AND MARKET ANALYSES. Less than $5 \%$ of harvested fruit were unmarketable, 
Table 1. Sources and prices of materials used to produce grafted and nongrafted cucumber transplants.

\begin{tabular}{|c|c|c|c|c|}
\hline Item & Description & Unit & Price (\$/unit) & Source \\
\hline 'Flexifort' hybrid squash rootstock ${ }^{z}$ & Rootstock & 1000 seeds & 114.00 & Osborne Quality, Mount Vernon, WA \\
\hline 50 -cell trays & Seedling tray & Tray & 1.05 & \\
\hline Spring loaded side-grafting clip & Grafting clips & Pack of 200 & 51.12 & Johnny's Selected Seeds \\
\hline
\end{tabular}

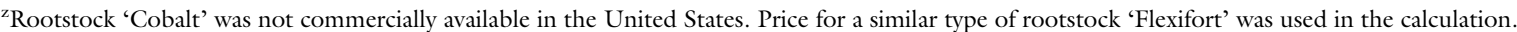

y'Sun Gro professional growing mix included starter fertilizers, no additional fertilizers were added during transplant production.

Table 2. Partial costs of grafted and nongrafted cucumber plants.

\begin{tabular}{|c|c|c|c|c|}
\hline \multirow[b]{3}{*}{ Item } & \multicolumn{2}{|c|}{ Grafted plants } & \multicolumn{2}{|c|}{ Nongrafted plants } \\
\hline & Materials & Labor & Materials & Labor \\
\hline & \multicolumn{2}{|c|}{$\overline{(\$ / 1000 ~ p l a n t s)}$} & \multicolumn{2}{|c|}{ (\$/1000 plants) } \\
\hline \multicolumn{5}{|l|}{ Seeds } \\
\hline Scion & $466.62^{z}$ & & 373.29 & \\
\hline Rootstock & 150 & & & \\
\hline \multicolumn{5}{|l|}{ Seeding production } \\
\hline Potting soil & 40.23 & & 23.16 & \\
\hline Trays & 38.4 & & 22.11 & \\
\hline Seed sowing and care & - & $96.66^{y}$ & - & 65.75 \\
\hline \multicolumn{5}{|l|}{ Grafted transplant production } \\
\hline Grafting labor & - & $157.01^{\mathrm{x}}$ & - & \\
\hline Grafting clips & 336.11 & & & \\
\hline Miscellaneous suppliesw & 20 & & & \\
\hline Post-grafting care & & $23.88^{\mathrm{v}}$ & & \\
\hline Total cost & 13 & & & \\
\hline Cost/plant & & & & \\
\hline
\end{tabular}

${ }^{\mathrm{z}}$ Germination rate at $95 \%$ was used to calculate all the seeds. Graft successful rate at $80 \%$ was used in the calculation of seeds and materials for producing grafted plants.

${ }^{y}$ Labor required for sowing seeds and caring seedlings was estimated at $8.09 \mathrm{~h}$ for grafted plants production and $5.51 \mathrm{~h}$ for nongrafted plants production. $\$ 11.94 / \mathrm{h}$ pay wage for all labor based on Indiana State Occupational Employment and Wage Estimates, May 2018 (U.S. Department of Labor, 2019).

${ }^{x}$ Grafting speed was estimated at 100 plants per person per hour.

${ }^{\mathrm{w}}$ Miscellaneous supplies for producing grafted plants include razor blade, sanitizer, paper towels, and clear plastic.

${ }^{\mathrm{v}} \mathrm{A}$ total of $2 \mathrm{~h}$ was estimated to take care of grafted plants for the $7 \mathrm{~d}$ post-grafting care.

thus only marketable yield for years 2017-19, as well as the 3 -year average for grafted and nongrafted treatments are presented in Fig. 1. Grafted plants had higher annual marketable yield than nongrafted plants in 2017, 2018 , and 2019 with $14.96,20.22$, and $12.17 \mathrm{lb}$, respectively. Grafted cucumber had a 3-year average yield of $15.78 \mathrm{lb} /$ plant, whereas nongrafted plants had a 3 -year average yield of $10.91 \mathrm{lb} /$ plant. Few unmarketable fruit were harvested regardless of treatments.

Table 3 illustrated the partial profit analysis for grafted and nongrafted plants when selling cucumber at different markets (i.e., farmers markets and retail). Partial profit per plant is the gross revenue per plant minus the partial production cost per plant, which is the sum of partial grafted transplant cost and partial harvesting/pruning cost. Results indicated that grafted cucumber resulted in higher partial profit per plant compared with nongrafted $\mathrm{cu}^{-}$ cumber. Similarly, selling at farmers markets resulted in higher partial profit per plant than selling through retail channels. For example, partial profit for grafted plants was $\$ 13.89$, $\$ 4.54$, and $\$ 2.07$ higher than nongrafted plants when sold at farmers markets for years 2017-19, respectively. When selling cucumber through retail channels, partial profit for grafted plants was $\$ 8.48$, $\$ 2.43$, and $\$ 0.83$ higher than nongrafted plants for years 2017-19, respectively.

Table 3 also showed the computed 3-year average partial profits per plant. On the basis of the 3-year average, results suggested that grafted cucumber provided higher returns than nongrafted plant when sold at farmers markets than retail stores.
Grafted cucumber had higher 3-year partial profit when sold at farmers markets (\$24.61/plant) than nongrafted cucumber ( $\$ 17.77 /$ plant). Similarly, grafted cucumber plant had higher 3-year partial return when sold at retail market (\$15.13/plant) than nongrafted plants (\$11.22/plant). Higher partial profit for grafted cucumber plants was mainly due to higher marketable yields than those recorded for nongrafted cucumber plants. These results not only revealed that grafted plants had, on average, a higher partial revenue, but growers selling at farmers markets can take advantage of better prices and get a higher share of the consumers' dollars.

Sensitivity anAlysis. Sensitivity analysis using partial profit comparisons between grafted and nongrafted plants was presented in Table 4. It showed the change in partial profit as price and yield vary. Prices in Table 4 ranged from $\$ 1.10$ to $\$ 1.70$ per pound, while marketable yield was allowed to vary up to 3 standard deviations (SD) for grafted and nongrafted plants. The mean yield for nongrafted cucumber plants was only calculated to $-1 \mathrm{SD}$ to ensure positive values. Changes in price may be a result of market and demand trends, whereas changes in yield may be due to pest issues, cultivar variability, and management practices.

Partial profit of grafted cucumber was $\$ 19.87 /$ plant, which resulted from the 3-year average marketable yield of $15.78 \mathrm{lb} /$ plant at $\$ 1.40 / \mathrm{lb}$ of cucumbers. In contrast, partial profit of nongrafted cucumber was $\$ 14.49$ / plant, which resulted from the 3 -year average marketable yield of $10.9 \mathrm{l} \mathrm{lb} /$ plant at $\$ 1.40 / \mathrm{lb}$ of cucumbers. The difference in partial profit between grafted and nongrafted cucumber amounts to $\$ 5.38 /$ plant.

Results from Table 4 suggested that the economic feasibility of grafting is more important when yield 


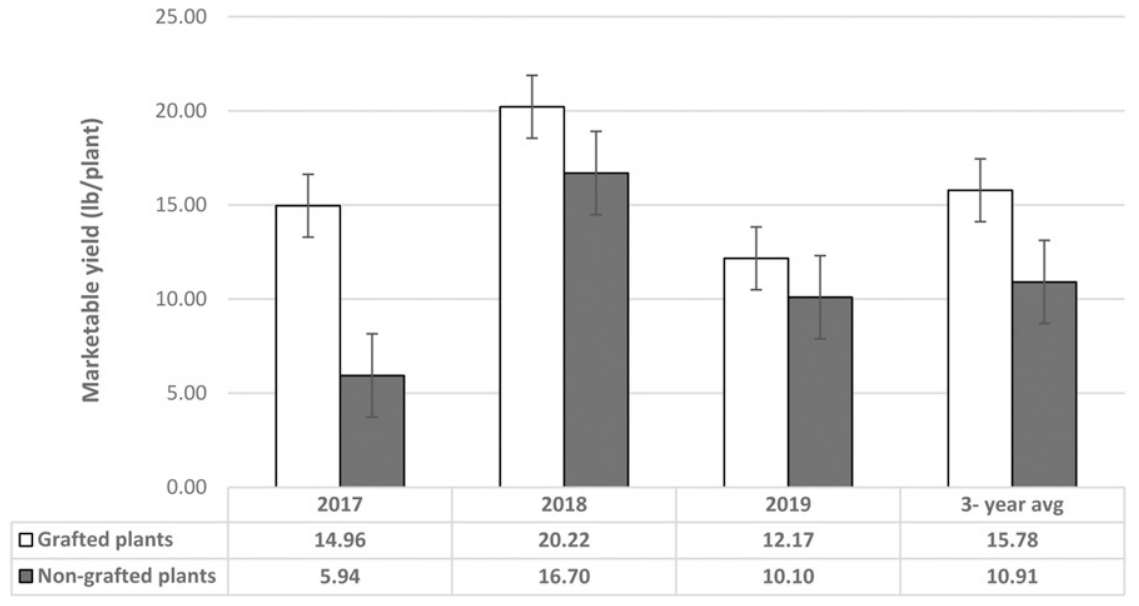

Fig. 1. Marketable yield for grafted and nongrafted 'Socrates' cucumber grown in a high tunnel at the Southwest Purdue Agricultural Center, Vincennes, IN, in 2017-19. $1 \mathrm{lb}=0.4536 \mathrm{~kg}$.

Table 3. Partial profits per plant for grafted and nongrafted 'Socrates' cucumber grown in a high tunnel at the Southwest Purdue Agricultural Center, Vincennes, IN, in 2017-19.

\begin{tabular}{|c|c|c|c|c|c|c|c|c|}
\hline & \multicolumn{4}{|c|}{$\begin{array}{l}\text { Sold at farmers' markets } \\
(\$ 1.7 / 1 \mathrm{~b})^{\mathrm{z}}\end{array}$} & \multicolumn{4}{|c|}{$\begin{array}{l}\text { Sold at retail markets } \\
\qquad(\$ 1.1 / 1 \mathrm{lb})\end{array}$} \\
\hline & 2017 & 2018 & 2019 & Avg & 2017 & 2018 & 2019 & Avg \\
\hline & \multicolumn{4}{|c|}{ Grafted plants } & \multicolumn{4}{|c|}{ Grafted plants } \\
\hline Yield (lb/plant) ${ }^{\mathrm{y}}$ & 14.96 & 20.22 & 12.17 & 15.78 & 14.96 & 20.22 & 12.17 & 15.78 \\
\hline Gross revenue $(\$ / \text { plant })^{x}$ & 25.43 & 34.37 & 20.68 & 26.83 & 16.46 & 22.24 & 13.38 & 17.36 \\
\hline \multirow[t]{2}{*}{ Partial profit ( $\$ /$ plant $)^{w}$} & 23.21 & 32.15 & 18.46 & 24.61 & 14.23 & 20.02 & 11.16 & 15.13 \\
\hline & \multicolumn{4}{|c|}{ Nongrafted plants } & \multicolumn{4}{|c|}{ Nongrafted plants } \\
\hline Yield (lb/plant) & 5.94 & 16.70 & 10.10 & 10.91 & 5.94 & 16.70 & 10.10 & 10.91 \\
\hline Gross Revenue ( $\$$ /plant) & 10.10 & 28.39 & 17.17 & 18.55 & 6.53 & 18.37 & 11.11 & 12.00 \\
\hline Partial profit ( $\$ /$ plant $)$ & 9.32 & 27.61 & 16.39 & 17.77 & 5.75 & 17.59 & 10.33 & 11.22 \\
\hline
\end{tabular}

${ }^{\mathrm{z}}$ Annual median farmers' market price (Purdue University, 2018) and annual median retail price (U.S. Department of Agriculture, 2018) were used in the calculation; $\$ 1 / 1 \mathrm{~b}=\$ 2.2046 / \mathrm{kg}$.

${ }^{\mathrm{y}} 1 \mathrm{lb}=0.4536 \mathrm{~kg}$.

${ }^{x}$ Gross revenue is the result of the multiplication of the yield and price.

"Partial profits is the gross revenue per plant minus the partial production cost per plant. Partial production cost per plant is the sum of partial grafted transplant cost $(\$ 1.33 /$ plant for grafted transplant and $\$ 0.48 /$ plant for nongrafted transplant) and partial harvesting/pruning cost ( $\$ 0.89$ /plant for grafted plants and $\$ 0.3 /$ plant for nongrafted plants).

decreases below the mean. For example, cucumber yield at 1 SD below the mean $(11.69 \mathrm{lb} /$ plant for grafted and $5.49 \mathrm{lb}$ for nongrafted cucumbers) sold at $\$ 1.40 / \mathrm{lb}$ resulted in partial profit of $\$ 14.15 /$ plant for grafted plants compared with $\$ 6.91$ / plant for nongrafted plants. In other words, the difference in partial profit between grafted and nongrafted cucumber when yield decreases by 1 SD from the mean amounts to $\$ 7.24 /$ plant, which is $\$ 1.86$ higher than the difference in returns at the average yield.

\section{Discussion and conclusions}

This study provided a baseline reference for growers interested in
$\$ 0.85 /$ plant (Barrett et al., 2012; Kubota et al., 2008). Similar to Djidonou et al. (2013) who found seeds (scion and rootstock) accounted for the highest expense in grafting tomato, we also found seeds as the highest expense in grafting cucumber [46\% (\$0.62/plant)]. With the advancement of more rootstock breeding initiatives, Djidonou et al. (2013) noted the potential decrease in rootstock prices.

Grafting labor accounted for $21 \%$ of the costs $(\$ 0.28 /$ plant $)$ for producing grafted plants. Whereas Kubota et al. (2008) implied that increased labor costs may represent the biggest expense deterring farmers to adopt grafting, our findings suggested that with access to skilled grafters, grafting labor may have less influence on the cost of grafted vegetable production compared with the other factors, such as rootstock, seed, and grafting materials. Yet skilled labor availability seems to be a major barrier to grafting and can greatly increase labor costs. It is important to note that grafting expertise and healing environment can greatly influence survival and quality of grafted plants. The production of grafted cucumbers may become more affordable with the development of new technologies that increase automation of grafting activities (Lee et al., 2010). Cucumber grafting was conducted by an experienced grafter in the current study; thus, a lower grafting survival rate and higher plant fatality may be expected from a new grafter. In addition, grafted plants were placed in a plant growth chamber with well-controlled temperature and light conditions. Grafting survival rate may be lower if a healing chamber was constructed in a greenhouse that often has larger environmental variations.

Although actual production costs for individual farmers may vary, our findings suggested that grafting is an economically viable approach for high tunnel cucumber production. Results from the sensitivity analysis illustrated how the increased yield of grafted cucumbers offset the extra cost incurred in the technique while providing a higher profit. Our findings from the sensitivity analysis validated that grafting is economically feasible for high tunnel cucumber production. Using grafted cucumber 
Table 4. Comparison of estimated partial profit per plant of grafted and nongrafted 'Socrates' cucumber as cucumber fruit price and marketable yield vary.

\begin{tabular}{|c|c|c|c|c|c|c|c|c|}
\hline \multirow[b]{3}{*}{ SD } & \multirow[b]{3}{*}{ Yield $(\mathrm{lb} / \text { plant })^{\mathrm{z}}$} & \multicolumn{7}{|c|}{ Cucumber price $(\$ / \mathrm{lb})^{\mathrm{y}}$} \\
\hline & & $\$ 1.10$ & $\$ 1.20$ & $\$ 1.30$ & $\$ 1.40$ & $\$ 1.50$ & $\$ 1.60$ & $\$ 1.70$ \\
\hline & & \multicolumn{7}{|c|}{$\overline{\text { 3-yr avg partial net return ( } \$ / \text { plant })}$} \\
\hline & & \multicolumn{7}{|c|}{ Grafted cucumber plants } \\
\hline-3 & 3.52 & 1.65 & 2.00 & 2.36 & 2.71 & 3.06 & 3.41 & 3.76 \\
\hline-2 & 7.60 & 6.14 & 6.90 & 7.66 & 8.42 & 9.18 & 9.94 & 10.70 \\
\hline-1 & 11.69 & 10.64 & 11.81 & 12.98 & 14.15 & 15.32 & 16.48 & 17.65 \\
\hline Mean & 15.78 & 15.14 & 16.72 & 18.29 & 19.87 & 21.45 & 23.03 & 24.61 \\
\hline+1 & 19.87 & 19.64 & 21.62 & 23.61 & 25.60 & 27.59 & 29.57 & 31.56 \\
\hline+2 & 23.96 & 24.14 & 26.53 & 28.93 & 31.32 & 33.72 & 36.12 & 38.51 \\
\hline \multirow[t]{2}{*}{+3} & 28.05 & 28.64 & 31.44 & 34.25 & 37.05 & 39.86 & 42.66 & 45.47 \\
\hline & & \multicolumn{7}{|c|}{ Nongrafted cucumber plants } \\
\hline-1 & 5.49 & 5.26 & 5.81 & 6.36 & 6.91 & 7.46 & 8.00 & 8.55 \\
\hline Mean & 10.91 & 11.22 & 12.31 & 13.40 & 14.49 & 15.59 & 16.68 & 17.77 \\
\hline+1 & 16.34 & 17.19 & 18.83 & 20.46 & 22.10 & 23.73 & 25.36 & 27.00 \\
\hline+2 & 21.76 & 23.16 & 25.33 & 27.51 & 29.68 & 31.86 & 34.04 & 36.21 \\
\hline+3 & 27.19 & 29.13 & 31.85 & 34.57 & 37.29 & 40.01 & 42.72 & 45.44 \\
\hline . & $\mathrm{N} .1 \mathrm{lb}=0.4536 \mathrm{k}$ & & & stimate & ean vie & or oraft & lants & $\begin{array}{l}\text { ased on } \\
\text { Center, }\end{array}$ \\
\hline
\end{tabular}

plants demonstrated great potential for maintaining cucumber yield and remaining profitable. In other words, grafting could be critical for growers dealing with low soil temperatures. Given the impact on yield and profitability, we expect that more growers in the United States will consider using grafted cucumber transplants. In addition, our study sheds light on the higher prices, on average, that famers can obtain by selling their produce through farmers markets compared with retail stores.

\section{Limitations}

Annual median farmers' market price and annual median retail market price were used in the current analyses without considering fluctuation of cucumber market price during the season. Farmers are likely to receive premium prices in the early-season market and gain advantage of attracting consumers to the farm stand by being the first seller of cucumbers in the market during early seasons. Future research from our team will focus on monthly revenue analysis to highlight the benefits of early harvest and spring price premiums for cucumbers.

Cucumber farmers must understand the benefits and limitations associated with grafting technology. Further research should examine the economic feasibility of grafting under different healing conditions that are readily available to small-scale farmers, such as a self-constructed healing chamber inside greenhouse. Graft survival rate will largely depend on the healing environment as well as the experience of grafters. Further research should also investigate the potential of purchasing grafted cucumber plants. With the increased recognition of the benefits that can be achieved by growing grafted cucumbers in high tunnels, current vegetable grafting nurseries are likely to expand the business and start to sell grafted cucumber plants. Additional research should also perform a complete economic study including, for example, break-even analyses to fully evaluate the cost and benefit that our current study did not encompass.

\section{Literature cited}

Alimi, T. and V.M. Manyong. 2000. Partial budget analysis for on-farm research. Res. Guide 65. Intl. Inst. Trop. Agr., Ibadan, Nigeria.

Barrett, C.E., X. Zhao, and A.W. Hodges. 2012. Cost benefit analysis of using grafted transplants for root-knot nematode management in organic heirloom tomato production. HortTechnology 22:252-257, doi: 10.21273/HORTTECH.22.2.252.
Carey, E.E., L. Jett, W.J. Lamont, T.T. Nennich, M.D. Orzolek, and K.A. Williams. 2009. Horticultural crop production in high tunnels in the United States: A snapshot. HortTechnology 19:37-43, doi: 10.21273/HORTSCI.19.1.37.

Djidonou, D., Z. Gao, and X. Zhao. 2013. Economic analysis of grafted tomato in sandy soils in northern Florida. HortTechnology 23:613-621, doi: 10.21273/ HORTTECH.23.5.613.

Egel, D., E. Maynard, S. Meyers, M. Babadoost, D. Lewis, C. Rivard, M. Hausbeck, B. Hutchison, T. Eaton, C. Welty, and S. Miller. 2019. Midwest vegetable production guide for commercial growers. Purdue Univ. Ext. Publ. ID56. 20 Jan. 2020. <https://www. extension.purdue.edu/extmedia/ID / ID-56-W\%202020.pdf>.

Greene, C.R., C. Dimitri, B.H. Lin, W.D. McBride, L. Oberholtzer, and T.A. Smith. 2009. Emerging issues in the US organic industry. USDA Economic Info. Bul. No. 55, doi: 10.22004/ag.econ.58617.

Guan, W., D.S. Egel, L.D. Sutterer, and A.D. Plummer. 2018. Early-season production of grafted seedless cucumbers in high tunnels. HortTechnology 28:74-79, doi: 10.21273/HORTTECH03910-17.

Guan, W. 2019. How to splice graft cucumber plants. Purdue Ext. Publ. HO328-W. 20 Jan. 2020. <https://www. extension.purdue.edu/extmedia/HO/ HO-328-W.PDF>.

Guan, W., D. Haseman, and D. Nowaskie. 2020. Rootstock evaluation for grafted cucumbers grown in high tunnels: Yield and plant growth. HortScience 55:914-919, doi: 10.21273/HORTSCI14867-20.

Hunter, B., D. Drost, B. Black, and R. Ward. 2012. Improving growth and productivity of early-season high-tunnel tomatoes with targeted temperature additions. HortScience 47:733-740, doi: 10.21273/HORTSCI. 47.6.733.

Knewtson, S.J., E.E. Carey, and M.B. Kirkham. 2010. Management practices of growers using high tunnels in the central great plains of the United States. HortTechnology 20:639-645, doi: 10.21273/ HORTTECH.20.3.639.

Kubota, C., M.A. McClure, N. KokalisBurelle, M.G. Bausher, and E.N. Rosskopf. 2008. Vegetable grafting: History, use, and current technology status in North America. HortScience 43:1664-1669, doi: 10.21273/HORTSCI.43.6.1664.

Lamont, W.J. 2009. Overview of the use of high tunnels worldwide. HortTechnology 19:25-29, doi: 10.21273/ HORTSCI.19.1.25. 
Lee, J.M., C. Kubota, S.J. Tsao, Z. Bie, P.H. Echevarria, L. Morra, and M. Oda. 2010. Current status of vegetable grafting: Diffusion, grafting techniques, automation. Scientia Hort. 127:93-105, doi: 10.1016/j.scienta.2010.08.003.

Louws, F.J., C.L. Rivard, and C. Kubota. 2010. Grafting fruiting vegetables to manage soilborne pathogens, foliar pathogens, arthropods and weeds. Scientia Hort. 127:127-146, doi: 10.1016/j.scienta.2010.09.023.

Meyer, L. 2016. Grafting to increase high tunnel tomato productivity in the central United States. MS Thesis, Kansas State Univ., Manhattan. 17 Dec. 2020. <https:// krex.k-state.edu/dspace/bitstream/ handle/2097/32736/LaniMeyer2016.pdf? sequence $=5$ \&isAllowed $=\mathrm{y}>$.

Purdue University. 2018. Indiana price reports. I Sept. 2020. <https://hort. purdue.edu/hortbusiness $>$.

Purdue University. 2020. INCLIMATE climate maps, 2020. 8 Dec. 2020. <https:// ag.purdue.edu/indiana-state-climate/ $>$.

Rivard, C.L., O. Sydorovych, S. O' Connell, M.M. Peet, and F.J. Louws. 2010. An economic analysis of two grafted tomato transplant production systems in the United
States. HortTechnology 20:794-803, doi: 10.21273/HORTTECH.20.4.794.

Rysin, O., C. Rivard, and F.J. Louws. 2015. Is vegetable grafting economically viable in the United States: Evidence from four different tomato production systems. Acta Hort. 1086:79-86, doi: 10.17660/ ActaHortic.2015.1086.8.

Sydorovych, O., C.D. Safley, R.M. Welker, L.M. Ferguson, D.W. Monks, K. Jennings, J. Driver, and F.J. Louws. 2008. Economic evaluation of methyl bromide alternatives for the production of tomatoes in North Carolina. HortTechnology 18:705-713, doi: 10.21273/HORTTECH.18.4.705.

Schwarz, D., Y. Rouphael, G. Colla, and J.H. Venema. 2010. Grafting as a tool to improve tolerance of vegetables to abiotic stresses: Thermal stress, water stress and organic pollutants. Scientia Hort. 127:162171, doi: 10.1016/j.scienta.2010.09.016.

Taylor, M., B. Bruton, W. Fish, and W. Roberts. 2008. Cost benefit analyses of using grafted watermelon transplants for fusarium wilt disease control. Acta Hort. 782:343-350, doi: 10.17660/ActaHortic. 2008.782.43.
Torres, A.P., M.I. Marshall, C.E. Alexander, and M.S. Delgado. 2017. Are local market relationships undermining organic fruit and vegetable certification? A bivariate profit analysis. Agr. Econ. 48:197205, doi: 10.1111/agec.12326.

U.S. Department of Agriculture. 2018. Agricultural prices.10 July 2020. <https:// usda.library.cornell.edu/concern/ publications $/ \mathrm{c} 82$ lgj76b?locale $=\mathrm{en}>$.

U.S. Department of Agriculture. 2020a. Statistics by subject. 6 Dec. 2020 . <https:// www.nass.usda.gov/Statistics_by_Subject/ result.php?34E78AA9-30E1-31F5A37AB19C0AF013E8\&sector $=$ CROPS\& g r o u p $=$ V E G E T A B L E S \& comm $=$ CUCUMBERS $>$.

U.S. Department of Agriculture. 2020b. Per capita consumption of fresh cucumbers in the United States from 2000 to 2019 (in pounds). 5 Nov. 2020. <https://www.ers. usda.gov/webdocs/DataFiles/8855l/ General.pdf? $v=0>$.

U.S. Department of Labor. 2019. May 2019 national industry-specific occupational employment and wage estimates. 12 May 2020. <https://www.bls.gov/ oes/current/naics2_11.htm>.

Welbaum, G.E. 2015. Vegetable production and practices. CABI, Wallingford, UK. 